\title{
Pharmacoeconomics: the impact of its applicability in a hospital foundation
}

\author{
Farmacoeconomia: o impacto de sua aplicabilidade em uma fundação hospitalar
}

Farmacoeconomía: el impacto de su aplicabilidad en la fundación de un hospital

Rauana Fagundes Silva1 ${ }^{1}$, Fernanda Pinheiro Leite', Karen Suzanne Alves Ferreira Severino ${ }^{1}$, João Bosco Costa ${ }^{2}$, Wellington Danilo Soares ${ }^{3}$, André Fabricio Pereira da Cruz ${ }^{4 *}$.

\begin{abstract}
Objective: To analyze the impact of the adopting of pharmacoeconomic practices in a Fundação Hospitalar. Methods: This is a cross-sectional and quantitative documentary research, carried at a Fundação Hospitalar. The data collected, resulting from 377 pharmacoeconomic interventions, described, structured and processed in templates and quantitative analysis of these data was carried out through the SPSS 24.0 program (Statistical Package for the Social Sciences) for Windows. Results: I observed that $58.63 \%$ of the interventions were validated, not for the purpose of moving. However, after the interventions that provide for the purpose of moving, a reduction of two expenses from $R \$ 27,692.07$ to $R \$ 1,793.96$ is obtained, resulting in an economy of $R \$ 25,898.11$ during the year. O ciprofloxacin was responsible for the greater economy, representing $69.52 \%$. When comparing or custody of treatment between the injectable and tablet pharmaceutical forms, it is observed a difference of $R \$ 972.16$. Conclusion: With the pharmacoeconomic interventions, a significant economy of approximately 26 thousand reais was obtained, enabling or employing two resources against other demands of the hospital foundation.
\end{abstract}

Keywords: Pharmacoeconomics, Costs, Medications.

\section{RESUMO}

Objetivo: Analisar o impacto da adoção de práticas farmacoeconomicas em uma Fundação Hospitalar. Métodos: Trata-se de uma pesquisa documental, transversal e quantitativa, realizada em uma Fundação Hospitalar. Os dados coletados, resultantes de 377 intervenções farmacoeconomicas, foram descritos, estruturados e processados em planilhas e realizada análise quantitativa destes dados através do programa SPSS 24.0 (Statistical Package for the Social Sciences) for Windows. Resultados: Observou-se que em $58,63 \%$ das intervenções avaliadas, não foram aceitas propostas de mudança. No entanto, nas intervenções que foram aceitas propostas de mudanças, obteve-se uma redução dos gastos de $R \$ 27.692,07$ para $R \$$ $1.793,96$, resultando em uma economia de $R \$ 25.898,11$ durante 0 ano. O ciprofloxacino foi o responsável pela maior economia representando 69,52\%. Ao comparar o custo de tratamento entre as formas farmacêuticas injetável e comprimido, observou-se uma diferença de $\mathrm{R} \$ 972,16$. E durante todos os meses do ano avaliado, constatou-se uma economia importante com a farmacoeconomia. Conclusão: Com as intervenções farmacoeconomicas, foi obtido uma economia significativa, possibilitando o emprego desses recursos em outras demandas da fundação hospitalar.

Palavras-chave: Farmacoeconomia, Custos, Medicamentos.

\section{RESUMEN}

Objetivo: Analizar el impacto de la adopción de prácticas farmacoeconómicas en una Fundación Hospitalaria. Métodos: Se trata de una investigación documental, transversal y cuantitativa, realizada en una Fundación Hospitalaria. Los datos recolectados, resultado de 377 intervenciones farmacoeconómicas, fueron descritos, estructurados y procesados en hojas de cálculo, y el análisis cuantitativo de estos datos se realizó mediante

\footnotetext{
1 Faculdade de Saúde Ibituruna (FASI), Montes Claros - MG.

2 Faculdade de Ciências Médicas Dr. José Antônio Garcia Coutinho, Três Corações - MG.

3 Universidade Estadual de Montes Claros (UNIMONTES), Montes Claros - MG.

${ }^{4}$ Universidade Federal de Minas Gerais (UFMG), Belo Horizonte - MG.

*E-mail: andrefabriciocruz@yahoo.com.br
}

SUBMETIDO EM: 5/2021

ACEITO EM: 6/2021

PUBLICADO EM: 6/2021 
el programa SPSS 24.0 (Statistical Package for the Social Sciences) para Windows. Resultados: Se observó que en el $58,63 \%$ de las intervenciones evaluadas no se aceptaron propuestas de cambio. Sin embargo, en las intervenciones en las que se aceptaron los cambios propuestos, se redujeron los gastos de $R \$ 27.692,07$ a $R \$ 1.793,96$, resultando en un ahorro de $R \$ 25.898,11$ durante el año. La ciprofloxacina fue la responsable de los mayores ahorros representando el $69,52 \%$. Al comparar el costo del tratamiento entre las formas farmacéuticas inyectables y en tabletas, hubo una diferencia de $R \$ 972,16$. Y durante todos los meses del año evaluados, hubo un ahorro importante con la farmacoeconomía. Conclusion: Con las intervenciones farmacoeconómicas se obtuvieron importantes ahorros, permitiendo el uso de estos recursos en otras demandas de la fundación hospitalaria.

Palabras clave: Farmacoeconomía, Costos, Medicamentos.

\section{INTRODUCTION}

The populational aging, it's morbimortality and the introduction of the new medical technologies brings economic implications, increasing health expenditures. These health expenditures have been growing at an accelerated rate worldwide, concerning users, governs and societies. The economy searches for solutions, benefits and a better way to distribute the public resources, aware of its shortage and limitations. Furthermore, the pharmaceutical interventions performed in the hospital environment, besides contributing to measure the expenditures, also provides clinical benefits, for example, identifying problems related to medicines (AGUIAR KS, et al., 2018; MAGEDANZ L, et al., 2012).

When it comes to reducing costs in the hospital area, this becomes a difficult task, due to the particularity of the care provided. Despite the difficulties, the recovery of hospital costs seeks to optimize expenses, financial balance, increase the recovery of the service provided to patients. Improving quality and effectiveness means achieving higher levels of health with qualified resources, without losing the quality of treatment (BHOWMIK D, et al., 2014).

The purchase of medicines in the public service considers the lowest price and the best quality. It is important that it is carried out in a rational manner, ensuring the minimization of public service spending on health. Qualified indicators must also be created for monitoring drug expenditures within the hospital pharmacy, thus guaranteeing medications in the quantity necessary to meet demand, avoiding shortages and promoting the rational use of medications (DE CARVALHO MP, et al., 2014).

The hospital pharmacy is responsible for meeting necessary demands to certify that the prescribed medicines are rationally used. Pharmacoeconomic project's helps to minimize an irrational pharmacotherapy, besides generating savings on the hospital expenditures. The medicines are essential on public healthcare. They are an economic commodity and is hardly available in an enough amount to meet the public healthcare system demands, becoming an important tool to minimize costs (DE SENA PS, et al., 2012; RAI M and GOYAL $R, 2018)$.

Pharmacoeconomics are a type of application of economy over the studies of medicines without reducing its therapeutic efficacy, aiming not to only reduce health expenditures, but promoting strategies that enable a quality treatment for the patients, with the least health expenditures (BROWN GC e BROWN MM, 2016; IVANOVA ZI and IVANOV YY, 2019; PRADELLI L, et al., 2020).

The term arose in Australia and has as an objective to analyze, describe and compare the costs and benefits. It is a field that has been growing significantly in the past years. The economic evaluation associates a set of procedures with the purpose of identify and quantify the effects on the patient's health, comparing pharmacologic alternatives due to its cost-benefit (WANG AS and GUNZLER AS, 2019).

One of the components of the pharmacoeconomics studied is cost. The cost assessment can be subdivided into direct costs that are related to health services, length of stay in the hospital, expenses with materials and medicines and indirect costs that are related to the productivity of patients or even family members, change in quality of life (BROWN GC and BROWN NM, 2016). Pharmacoeconomic analysis relates to total treatment costs, which can be divided into four main types: cost minimization analysis, cost-benefit analysis, costeffectiveness analysis, cost-utility analysis (BHOWMIK D, et al., 2014). 
The cost minimization analysis (CMA) is the simplest analysis, they are equivalent in their therapeutic results, considering the direct costs. This type of analysis is only indicated when the results are the same, as they compare two alternatives that have the same benefits, an example is the use of a drug in different ways that will obtain the same therapeutic efficacy, prioritizing the one that has a lower cost (DAS NEVES RRS and BARBOSA IC, 2019).

Cost-benefit analyzes (CBA) are measured in monetary values, it was once one of the most used analyzes by health institutions, but currently there is a low acceptance for this type of analysis. For the application of the cost-benefit analysis, a parallel is made between the costs (investment) of the treatment in relation to the benefits (consequences) caused by it, the purpose of this type of analysis is to establish a relationship between the costs and benefits achieved, either directly or indirectly. indirectly (ONUWUGA E, et al., 2016; ARNOLD RJG, 2021).

The cost-effectiveness analyzes (CEA) aim to evaluate the effects generated by two or more types of pharmacological treatments, in this type of analysis it is important to always compare and evaluate the therapies to be used, always choosing the one that is most effective at a cost smaller. The costs are indicated in monetary values and the benefits in effectiveness and therapeutic efficacy, for example, number of deaths avoided, shorter hospital stay, reduction in the number of symptoms, minimization of pathologies (ARNOLD RJG, 2021).

The cost-utility analysis (AUC) is concerned with the time and quality of survival, it is a comparison of costs / consequences and the consequences are quantified in a qualitative way. Its result involves the quality measured by the years of life, a tool called quality-adjustedlife-years (QUALYs) is used that is mirrored in social preferences, it uses a combination of mortality which is quantity of life and morbidity which is quality of life (ARNOLD RJG, 2021).

Given the importance of hospital pharmacoeconomics, the objective of this study was to evaluate the impact of pharmacoeconomics on a Hospital Foundation by comparing the results obtained with pharmacoeconomic interventions.

\section{METHODS}

This is a quantitative, cross-sectional and documentary research which the data were obtained through a database of pharmacoeconomic interventions made in a hospital foundation located in a city in the northern of the Minas Gerais state. This was a non-probabilistic sample study made through the sheets of the pharmacoeconomic interventions of the hospital foundation in question. This study analyzed the information of the interventions made from January to December 2018, adding up to a total of 377 evaluated interventions.

Were included in this research all the pharmacoeconomic interventions made in the period of January to December 2018 which were with complete and clear information. Were excluded all the spreadsheets which showed difficult to interpretate the data on it as the ones with no continuing fill.

The collected information was inserted in spreadsheets, indicators and charts through the pharmacist responsible for the department of pharmacoeconomic of the institution researched. The variables collected were: medicines involved in the intervention, number of patients with interventions made, number of patients with accepted doses and the change to oral use, quantity of doses which were accepted and non-accepted to oral use change, cost per intravenous and oral administration, money saving obtained per each medication, value spent with doses which were non-accepted the change for oral use.

The collected data were described, structured and processed in spreadsheets on the software of Microsoft Excel 2013 version and, the quantitative analysis of these data was made through the Statistical Package for the Social Sciences (PSS) 24.0 software for Windows. It was used the independent t-student test to evaluate the average of the data of two groups considering significate $p \leq 0,05$.

The work was submitted and approved by the Research Ethics Committee of Brazil's Educational Association (SOEBRAS) under opinion 3.193.737/2019, and for being a research with secondary data (database), the use of the Free and Informed Consent Term (TCLE) was dismissed. 


\section{RESULTS}

The study sample was composed by 377 evaluated interventions. It was observed that in $58,63 \%(n=221)$ wasn't accepted the proposals of change from injectable administration to oral use and in $41,37 \%(n=156)$ there were accepted interventions to change to oral use. There was statistical support indicating significant difference $(p=0,001)$ between these groups (Figure 1).

Figure 1 - Accession of the institution's clinical staff related to the replacement of the administration route, $\mathrm{n}=377$.

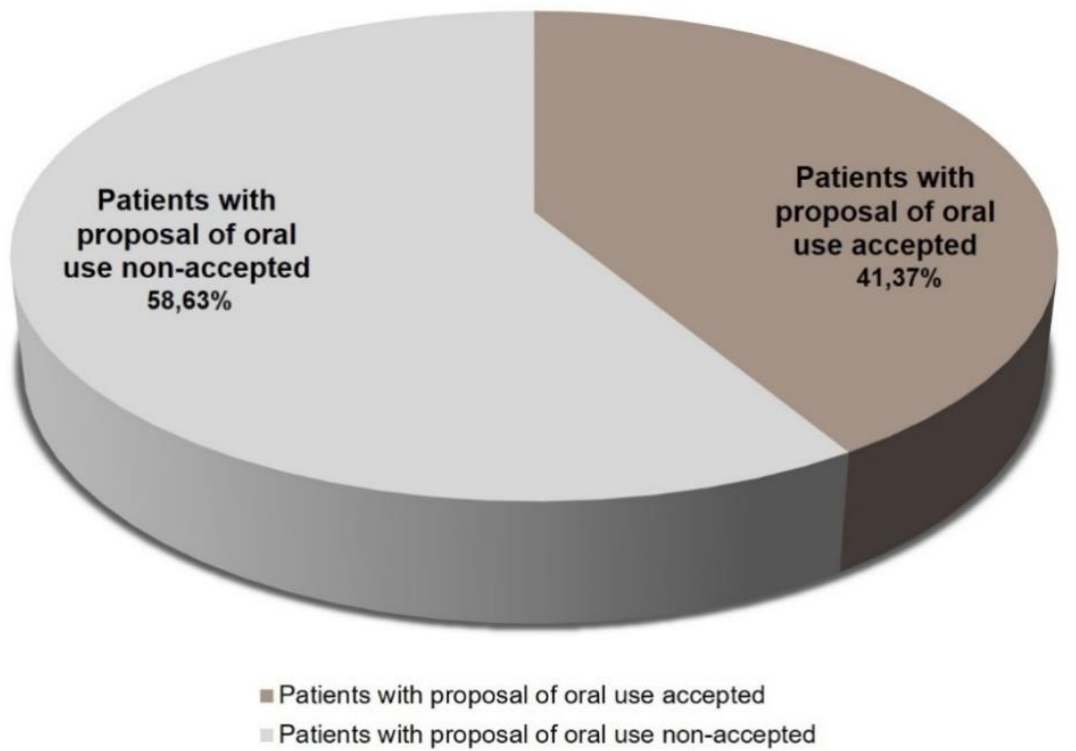

Source: Silva RF, et al., 2021.

With regard to the monthly costs and to their economies, it was observed a significant variation $(p<0,05)$. Is emphasized that the costs are exclusively of the unit value of each ampoule. It was not included the expense with diluent materials used for intravenous administration, neither the cost by time spent for administration and hospitalization time. It was approximately 26 thousand reais of money saving during the evaluated period, considering only the replacement of the administration route (Table 1).

Table 1 - Distribution of monthly values saved with the replacement of administration route.

\begin{tabular}{ccccc}
\hline Month & Expected costs & Amount spent & Money saving & Sig \\
\hline January & $\mathrm{R} \$ 1208,14$ & $\mathrm{R} \$ 179,49$ & $\mathrm{R} \$ 1028,65$ & \\
February & $\mathrm{R} \$ 2406,80$ & $\mathrm{R} \$ 123,59$ & $\mathrm{R} \$ 2283,21$ & \\
March & $\mathrm{R} \$ 4152,38$ & $\mathrm{R} \$ 216,66$ & $\mathrm{R} \$ 3935,72$ & \\
April & $\mathrm{R} \$ 3309,94$ & $\mathrm{R} \$ 278,96$ & $\mathrm{R} \$ 3030,98$ & \\
May & $\mathrm{R} \$ 1656,20$ & $\mathrm{R} \$ 189,84$ & $\mathrm{R} \$ 1466,36$ & \\
June & $\mathrm{R} \$ 3623,82$ & $\mathrm{R} \$ 116,04$ & $\mathrm{R} \$ 3507,78$ & $0,000^{*}$ \\
July & $\mathrm{R} \$ 1205,17$ & $\mathrm{R} \$ 73,50$ & $\mathrm{R} \$ 1131,67$ & \\
August & $\mathrm{R} \$ 1729,80$ & $\mathrm{R} \$ 83,10$ & $\mathrm{R} \$ 1646,70$ & \\
September & $\mathrm{R} \$ 3786,80$ & $\mathrm{R} \$ 182,72$ & $\mathrm{R} \$ 3604,08$ & \\
October & $\mathrm{R} \$ 2178,70$ & $\mathrm{R} \$ 178,53$ & $\mathrm{R} \$ 2000,17$ & \\
November & $\mathrm{R} \$ 807,96$ & $\mathrm{R} \$ 112,68$ & $\mathrm{R} \$ 695,28$ & \\
December & $\mathrm{R} \$ 1626,36$ & $\mathrm{R} \$ 58,85$ & $\mathrm{R} \$ 1567,51$ & \\
TOTAL & $\mathrm{R} \$ \mathbf{2 7 6 9 2 , 0 7}$ & $\mathrm{R} \$ \mathbf{1 7 9 3 , 9 6}$ & $\mathrm{R} \$ \mathbf{2 5 8 9 8 , 1 1}$ & \\
\hline
\end{tabular}

Source: Silva RF, et al., 2021.

In relation to the percentage distribution of the medicines which showed the most annual money saving, it was observed a significant variation $(p<0,05)$ between the determined active principles, and, Ciprofloxacin showed the most annual money saving representing $69,52 \%$ followed by Clindamycin $15,83 \%$ and Azithromycin 6,78\% (Figure 2). 
Figure 2 - Percentage distribution of medicines which showed the most annual money saving.

\begin{tabular}{|c|c|c|}
\hline CIPROFLOXACIN & & 69,52 \\
\hline CLINDAMYCIN & 15,83 & \\
\hline AZITHROMYCIN & 6,78 & \\
\hline METRONIDAZOLE & 2,66 & \\
\hline $\begin{array}{l}\text { AMOXICILLIN + } \\
\text { CLAVULANATE }\end{array}$ & 2,36 & \\
\hline $\begin{array}{c}\text { DIPYRONE } \\
\text { (METAMIZOLE) }\end{array}$ & 1,38 & \\
\hline RANITIDINE & 0,69 & \\
\hline FUROSEMIDE & 0,56 & \\
\hline DEXAMETHASONE & 0,14 & \\
\hline & - \% annual saving & $b=0,00$ \\
\hline
\end{tabular}

Source: Silva RF, et al., 2021.

A monthly average was also surveyed in relation to the number of doses used and the average monthly cost, both the medicine administrated orally and intravenously. It was found in this study that the monthly average value compared to the oral and intravenously use was significant $(p<0,05)$ to every surveyed medicine in the study (Table 2).

Table 2 - Comparison of the costs of administration routes and the average monthly cost.

\begin{tabular}{ccccc}
\hline Medicines & $\begin{array}{c}\text { Monthly average } \\
\text { Used doses }\end{array}$ & Administration routes & $\begin{array}{c}\text { Monthly average } \\
\text { (Reais) }\end{array}$ & Sig \\
\hline Ciprofloxacin & 249 & $\begin{array}{c}\text { Injectable Oral } \\
\text { Injectable Oral }\end{array}$ & $\begin{array}{c}\mathrm{R} \$ 6036,81 \\
\mathrm{R} \$ 58,18\end{array}$ & $0,000^{*}$ \\
\hline $\begin{array}{c}\text { Amoxicillin + } \\
\text { Clavulanate }\end{array}$ & 45,6 & $\begin{array}{r}\text { Injectable Oral } \\
\text { Injectable Oral }\end{array}$ & $\begin{array}{c}\mathrm{R} \$ 348,05 \\
\mathrm{R} \$ 60,91\end{array}$ & $0,037^{*}$ \\
\hline Azithromycin & 6,4 & $\begin{array}{l}\text { Injectable Oral } \\
\text { Injectable Oral }\end{array}$ & $\begin{array}{c}\mathrm{R} \$ 315,32 \\
\mathrm{R} \$ 5,89\end{array}$ & $0,000^{*}$ \\
\hline Clindamycin & 399 & $\begin{array}{l}\text { Injectable Oral } \\
\text { Injectable Oral }\end{array}$ & $\begin{array}{c}\mathrm{R} \$ 1319,97 \\
\mathrm{R} \$ 343,10\end{array}$ & $0,008^{*}$ \\
\hline Dexamethasone & 37,7 & $\begin{array}{l}\text { Injectable Oral } \\
\text { Injectable Oral }\end{array}$ & $\begin{array}{c}\mathrm{R} \$ 38,79 \\
\mathrm{R} \$ 5,65\end{array}$ & $0,007^{*}$ \\
\hline Sulfamethoxazole & 16,4 & $\begin{array}{l}\text { Injectable Oral } \\
\text { Injectable Oral }\end{array}$ & $\begin{array}{c}\mathrm{R} \$ 44,32 \\
\mathrm{R} \$ 1,47\end{array}$ & $0,007^{*}$ \\
\hline Furosemide & 34,5 & $\begin{array}{l}\text { Injectable Oral } \\
\text { Injectable Oral }\end{array}$ & $\begin{array}{c}\mathrm{R} \$ 30,36 \\
\mathrm{R} \$ 1,38\end{array}$ & $0,000^{*}$ \\
\hline Metronidazole & 93,3 & $\begin{array}{l}\text { Injectable Oral } \\
\text { Injectable Oral }\end{array}$ & $\begin{array}{r}\mathrm{R} \$ 247,33 \\
\mathrm{R} \$ 7,46\end{array}$ & $0,000^{*}$ \\
\hline Omeprazole & 3,8 & $\begin{array}{l}\text { Injectable Oral } \\
\text { Injectable Oral }\end{array}$ & $\begin{array}{c}\mathrm{R} \$ 17,44 \\
\mathrm{R} \$ 0,23\end{array}$ & $0,041^{*}$ \\
\hline Ranitidine & 14,6 & $\begin{array}{l}\text { Injectable Oral } \\
\text { Injectable Oral }\end{array}$ & $\begin{array}{r}\mathrm{R} \$ 26,25 \\
\mathrm{R} \$ 1,31\end{array}$ & $0,049^{*}$ \\
\hline
\end{tabular}

Source: Silva RF, et al., 2021. 
It was performed the comparison of the treatment cost between two pharmaceutical forms: injectable and table of a medicine used in the Hospital Foundation researched. It was noted that with the application of the interchangeability, the cost of 980,00 reais corresponding to the treatment with intravenous rout becomes 7,84 reais, making a different value of 972,16 reais on the saving of resources spent with medicines (Table 3).

Table 3 - Comparison of the treatment cost between the pharmaceutical forms injectable $\mathrm{x}$ table.

\begin{tabular}{ccccc}
\hline Medicines & Posology & Treatment period & Unit cost (reais) & Total cost (reais) \\
\hline $\begin{array}{c}\text { Medicine "A" - } \\
\text { Injectable }\end{array}$ & $12 / 12 \mathrm{~h}$ & 14 days & $\mathrm{R} \$ 35,00$ & $\mathrm{R} \$ 980,00$ \\
$\begin{array}{c}\text { Medicine "A" - } \\
\text { Tablet }\end{array}$ & $12 / 12 \mathrm{~h}$ & 14 days & $\mathrm{R} \$ 0,28$ & $\mathrm{R} \$ 7,84$ \\
\hline
\end{tabular}

Source: Silva RF, et al., 2021.

\section{DISCUSSION}

Considering that health expenditures have been progressively increasing, due to several factors, such as the emergence and implantation of new technologies, variations in the epidemiological profile of society, economic evaluations have been shown to be increasingly necessary due to the scenario in which health is found. public. Due to this context, pharmacoeconomics is indispensable in decision making, in the acquisition and dispensation of medicines (DE FARIA ACM, et al., 2014). In this study, the analysis used to optimize the resources was the minimizing costs analysis, where the exchange of intravenous to oral administration routes is performed.

The pharmacist performs the prescription's analysis of the medicines which are prescribed in the injectable pharmaceutical form, observing technical details like the diet, because in patients in use of nasoenteric and nasogastric tube, the interchangeability is not performed. Beside these, in the tracheostomized patients and in use of mechanical ventilation, the administration route exchange becomes unviable. After this analysis, the intervention is performed along with the prescriber to evaluate the possibility of the interchangeability of the administration route/pharmaceutical form of each patient (YAGUDINA RI and SERPI VG, 2016).

Of the 377 interventions made, in $41,37 \%(n=156)$ were performed the replacement of the injectable route to oral route. This result is influenced by the clinical condition of the patient. The exchange is only possible when the patient is stable. In the case of the antimicrobial, for example, the exchange usually happens after three days of administration of the intravenous medicine (RALPH ACL, et al., 2014; DE OLIVEIRA AZULINO AC, et al., 2020). Replacing an injectable drug therapy with an oral therapy in addition to reducing costs increases patient safety, as it is changing the venous access that can be a source of infection, in addition to being a difficult route to reverse adverse events, with a therapy that will have same pharmacological effects with greater safety for the patient guaranteeing his clinical evolution in a positive way.

It was observed a significant variation related to the monthly saving $(p<0,05)$ of the surveyed medicine in the research. This variation in the saving may occur in function of the medicine, the prescriber's habits and, may still be intrinsically related to the patient's condition (DE CARVALHO MP, et al., 2014). These numbers reinforce that a simple replacement of administration route of a drug may turn to a considerable saving. And the saved values can be applied to other demands of the hospital unit.

A cost minimization analysis is a simple method that involves a cost comparison between two or more treatments that are therapeutically equivalent with the economic cost being a differentiating factor. Thus, if the equivalence is confirmed, it is possible to compare the result in relation to costs (BHOWIMIK D, et al., 2014). An example is the use of a medicine through different routes which are going to obtain the same therapeutical efficacy, prioritizing the one with lower costs (ONUWUGHA E, et al., 2016). The high bioavailability of the oral route allows the interchangeability between the administration routes. Therefore, the administration of medicines by oral route is widely used due to the many advantages on the parenteral routes, as the greater facility of administration, reduction of occurrence of adverse events, reduction of costs and time of hospitalization (DAS NEVES RRS and BARBOSA IC, 2019). And the results of this work have shown that replacing the route of administration can provide significant savings in the hospital. 
It is still low the acceptance of the clinical staff of the Hospital Foundation researched in relation to the replacement of the administration route; only $41,37 \%$ were accepted. Some professionals justify nonreplacement because the intravenous route has greater bioavailability in relation to the oral route, besides making impossible the interchangeability when it comes to severe patients. Furthermore, there is the lack of confidence from the clinical staff on the oral therapy and the consequence of the benefits offered by an eventual replacement of the administration drug route (RALPH ACL, et al., 2014; TAGUTI E, 2015). It is important to raise awareness and inform professionals, especially those directly involved with the patient's drug prescription, who evaluate the possibility of replacing the drug administration route when possible. This measure is important for minimizing costs without changing the patient's therapeutic outcome.

A study conducted in Canada, in tertiary teaching hospitals including Vancouver Hospital and Health Sciences Centre (VHHSC) - Vancouver - British Columbia; the University Health Network (UHN) - Toronto, Ontario; and Hôpital Maisonneuve-Rosemont - Montreal, Quebec, showed that 10,1\% of the patients changed from intravenous Vancomycin to an oral anti-infective, and, the reason mentioned to the low adhesion was that there wasn't an effective oral therapy available, bringing an uncertainty among the prescribers of an appropriate anti-infective oral therapy (CONLY JM, et al., 2003). In this study, the results related to the substitution of the administration route were superior. However, it is a percentage that can still be increased.

Despite the acceptance of the clinical staff being inferior than $50 \%$, sill it was registered a saving of $25.898,11$ reais during the study period. This value is considered significant to optimize the resources spent in medicines, because in this value saved wasn't included the expenditures with the medicine's administration, materials and diluents. In comparison with other studies performed in patients with renal problems from a university hospital in Switzerland, which showed a saving of $13,7 \%$ achieved with the exchange of the administration routes (DE CARVALHO MP, et al., 2014), it is considered bigger, with an average of $92,5 \%$ of monthly money saving. Therefore, it is necessary to check the reasons that limit the substitution of treatment with a cheaper one when possible in the hospital environment.

Evaluating the medicines individually, it was observed that the Ciprofloxacin showed the biggest saving: $69,52 \%$, followed by Clindamycin with $15,83 \%$ and Azithromycin with $6,78 \%$. This high percentage showed by Ciprofloxacin may be related to its high cost and its most prevalent prescription; 249 doses were used in the study period. Despite Azithromycin shows a bigger unit cost, it represented only $6,78 \%$ of the annual saving. This may be related to the fact of this drug has a posology and treatment period different than Ciprofloxacin (RALPH ACL, et al., 2014; TAGUTI E, 2015).

Ciprofloxacin was the most onerous injectable medicine for the institution, showing an average monthly cost of $R \$ 6.036,81$; while the same medicine in the table pharmaceutical form costed $R \$ 58,81$. Many studies show pharmacoeconomic aspects obtained with the drug replacement from injectable route to another one by oral route and even to another antimicrobial, providing a considerable saving (CYRIAC JM e JAMES EJJ, 2014; ZHANG L e HU PJ, 2017). And, in this study the ciprofloxacin replacement, when possible, already provides an important saving for the hospital foundation. This substitution has an important impact on pharmacoeconomics in the hospital environment and, at the same time, provides an effective and lower cost pharmacotherapy for the institution.

A study conducted in a public hospital in South Brazil also showed that the cost of the treatment on the hypothetical exchange of the administration route of linezolid was US $\$ 1991.33 \pm 946.39$ for the patients whom received the medicine in the intravenous group and US $\$ 1874.18 \pm 763.20$ in the mixed group (oral route and nasoenteric tube) (TAGUTI E, et al., 2015). As in this work, it can be seen that the substitution of the route of administration is an important alternative in pharmacoecomics.

The comparison between the costs of intravenous and oral administration route showed that the value spent for the treatment of 1 patient with the medicine " $A$ " intravenous is approximately the same value spent for treatment with medicine $A$ of 124 patients trough oral route. Thus, the application of the interchangeability provided a saving above 970,00 reais in only one treatment, and this saving is extremely important. The saving achieved with the performed interventions can be intended to new investments and applications on 
pharmacoeconomic service, as the elaborating of new strategies and pharmacoeconomic analysis to be applied in the institution. Brazilian studies shows that the pharmaceutical interventions provides both pharmacoeconomic and clinical benefits (TIGUMAN GB and RONALDO M, 2020).

Several studies demonstrate the benefits of pharmacoeconomic assessments. Da Costa Braúna C, et al. (2021), showed the impact of costs on drug treatment in a protocol used to treat COVID-19 used in a field hospital. Guilhon-Simplicio F, et al. (2014), studied the pharmacoeconomic aspects and clinical implications of the use of antimicrobials in a pediatric health unit and found the inappropriate use of these drugs. De Faria ACM, et al. (2014) after evaluating 11 studies indicated that Brazilian pharmacoeconomic studies are scarce and that it is necessary to expand pharmacoeconomic studies in order to promote a better allocation of financial resources in hospital units. Pharmacoeconomic assessments such as the one carried out in this study are important to ensure the best design in treatments with the best cost-benefit ratios.

Applying the concepts of pharmacoeconomy is very important in any hospital unit. Pharmacoeconomics is a tool that assists in decision making by assessing which drug is the best for the patient. In addition, as shown in this study, it contributes to minimizing costs that can be used in other areas of the hospital.

\section{CONCLUSION}

In this study, has been proved that the pharmacoeconomic interventions cost minimizing type, performed in the Hospital Foundation, is clinically effective and economically efficient in the provision of health care, because, besides generating a significant money saving during the evaluated period, they can also contribute to the rational use of medicines, increasing the patient's security and reducing the hospitalization period. Besides these benefits, it is highlighted that the oral administration route shows a good safety profile without prejudice the treatment's quality. Furthermore, it is emphasized the importance of new researches about pharmacoeconomic, once that studies related to this theme are still scarce.

\section{REFERENCES}

1. ARNOLD RJG. Pharmacoeconomics: from theory to practice. 2nd ed. CRC Press, $2021 ; 05$.

2. AGUIAR KDS, et al. Patient safety and the value of pharmaceutical intervention in a cancer hospital. Einstein (Sao Paulo), 2018; 16(1): eAO4122.

3. BHOWMIK D, et al. Revisão da Pharmacoeconomics-A. Pharmacy, 2014; 69: 23672-23675.

4. BROWN GC, BROWN MM. Value-Based Medicine and Pharmacoeconomics. Developments in ophthalmology, 2016; 55: 381-390.

5. CONLY JM, et al. A retrospective analysis of practice patterns in the treatment of methicillin-resistant Staphylococcus aureus skin and soft tissue infections at three Canadian tertiary care centres. Canadian Journal of infectious, 2003; 14(6): 315-321.

6. CYRIAC JM, JAMES EJJ. Switch over from intravenous to oral therapy: a concise overview. Journal of pharmacology \& pharmacotherapeutics, 2014; 5(2): 83.

7. DA COSTA BRAÚNA C, et al. Farmacoeconomia aplicada ao tratamento medicamentoso para a COVID-19 em um hospital campanha. Revista Eletrônica Acervo Saúde, 2021; 13(2): e5971-e5971.

8. DE CARVALHO MP, et al. Avaliações farmacoeconômicas em vigilância de medicamentos. Revista Saúde \& Ciência Online, 2014; 3(2): 43-57.

9. DE FARIA ACM, et al. Estudos Farmacoeconômicos no Brasil: onde estamos? Rev. Bras. Farm. Hosp. Serv. Saúde São Paulo, 2014; 5(4): 13-18.

10. DE OLIVEIRA AZULINO AC, et al. Intervenção farmacêutica na antibioticoterapia do idoso: caminhos para a redução da ocorrência de problemas relacionados a medicamentos e promoção da farmacoeconomia. Revista Eletrônica Acervo Saúde, 2020; 12(11): e4504-e4504.

11. DAS NEVES RRS, BARBOSA IC. Farmacoeconomia: uma estratégia para a gestão dos gastos com medicamentos no âmbito hospitalar. RACE-Revista de Administração do Cesmac, 2019; 5: 194-217.

12. DE SENA PS, et al. Farmacoeconomia: análise dos custos das prescrições medicamentosas na unidade de terapia intensiva de um hospital em Aracaju/SE. Infarma - Ciências Farmacêuticas, 2012; 22(9/10): 16-21.

13. GUILHON-SIMPLICIO F, et al. Aspectos farmacoeconômicos e implicações clínicas do uso de antimicrobianos em uma unidade de saúde pediátrica. Revista Brasileira de Farmácia Hospitalar e Serviços de Saúde, 2014; 5(2). 
14. IVANOVA ZI, IVANOV YY. Pharmacoeconomics of Bronchial Asthma. Folia medica, 2019; 61(2): 163-171.

15. MAGEDANZ L, et al. Impact of the pharmacist on a multidisciplinary team in an antimicrobial stewardship program: a quasi-experimental study. Int J Clin Pharm, 2012; 34(2): 290-29.

16. ONUKWUGHA E, et al. Cost-of-illness studies: an updated review of current methods. Pharmacoeconomics, 2016; 34(1): 43-58.

17. PRADELLI L, et al. Pharmacoeconomics of Parenteral Nutrition with $\omega-3$ Fatty Acids in Hospitalized Adults. JPEN Journal of parenteral and enteral nutrition, 2020; 44(1): S68-s73.

18. RAI M, GOYAL R. Pharmacoeconomics in healthcare. In: Pharmaceutical medicine and translational clinical research. Academic Press, 2018; 465-472.

19. RALPH ACL, et al. Aspectos farmacoeconômicos e implicações clínicas do uso de antimicrobianos em uma unidade de saúde pediátrica. Revista Brasileira de Farmácia Hospitalar e Serviços de Saúde, 2014; 5(2).

20. TAGUTI É, et al. Cost-minimization analysis of oral and intravenous administration of linezolid in a public hospital in southern Brazil. Revista de Ciências Farmacêuticas Básica e Aplicada, 2015; 36(4).

21. TIGUMAN GB, RONALDO M. Economic impact of pharmaceutical interventions on healthcare services from Brazil: a systematic review. Revista Brasileira de Farmácia Hospitalar e Serviços de Saúde, 2020; 11(4): 512.

22. ZHANG L, HU PJ. Cost-effectiveness analysis of oral versus intravenous drip infusion of levofloxacin in the treatment of acute lower respiratory tract infection in Chinese elderly patients. Clinical interventions in aging, 2017; $12: 673$.

23. WANG AS, GUNZLER SA. Systematic review of the pharmacoeconomics of Parkinson disease medications. Expert opinion on pharmacotherapy, 2019; 20(13): 1659-1670.

24. YAGUDINA RI, SERPIK VG. Methodological issues of pharmacoeconomic modeling. Pharmacoeconomics: theory and practice, 2016; 4(1): 13-18. 